\title{
Application of Bio-energy in Ecological Economy Construction
}

\author{
Guoying Zhang \\ Zhejiang Business College, Hangzhou, Zhejiang, China
}

\begin{abstract}
With the development of economy, environmental pollution especially the quality of atmosphere has become an urgent problem. Bio-energy is introduced first in this dissertation. Then the meaning of exploitation and utilization of bio-energy is analyzed. In the end, central heating project in Linan Banqiao town is introduced to provide a useful case for the reasonable utilization of bio-energy in ecological economy construction.
\end{abstract}

\section{The Bio-energy profile}

Bio-energy is a variety of organisms produced by photosynthesis and it's a kind of renewable carbon source which can be converted into regular solid, liquid and gaseous fuels. It's estimated that the amount of fixed carbon dioxide produced by plant photosynthesis is $2 \times 10^{11}$ ton in each year, which contains $3 \times 10^{21}$ joules of energy. This is 10 times the world's annual energy consumption.

Bio-energy spreads all over the world. Its form is various and its quantity is enormous. The total energy consumption of bio-energy is the fourth in the world, ranking only second to coal, petroleum and natural gas.There is an amount of 5 billion tons of biomass resources in China theoretically, which mainly contains firewood, crop straw, forest crop, agroforestry processing residues, livestock manure, household garbage, domestic sewage and aquatic plants, etc.

\section{The meaning of exploitation and utilization of bio-energy}

The utilization of bio-energy is of great significance to improve ecological environment and to realize harmonious development of economy, social and environment.

Bio-energy is a kind of renewable energy and its energy saving effect is obvious. Its price is the lowest in clean energy and the price is stable and reliable. Using bio-energy substitutes for fuel oil and natural gas can not only avoid the price fluctuation risk of fossil energy, but also realize the structural energy saving benefit. It can save 25,000 tons of standard coal per year for a customer whose steam capacity is 50 steam tons $/ \mathrm{h}$. A national financial award of 200 yuan can be applied for each ton of standard coal reduction according to current policies of NDRC. It's explicated that the utilization amount of bioenergy is included in the region's amount of emission reduction in the Twelfth Five-year Plan, but it is not included in the amount of total energy consumption limited to this region. Bio-energy utilization is taken more seriously by every region under above-mentioned policy. So the economic benefit is remarkable when using bioenergy.

When using bio-energy, greenhouse gas $\mathrm{CO}_{2}$ emitted from combustion is equivalent to the $\mathrm{CO}_{2}$ which is absorbed in its growing process, so the greenhouse gas is ecological "zero" emission. According to Kyoto protocol, $\mathrm{CO}_{2}$ emission reduction targets can be sold to international market when using bio-energy. So the emission reduction is very effective.

Expensive desulfurization and denitration equipment must be used when using coal and fuel oil. But the content of sulfur, nitrogen and ash in biomass fuel is so low that the national environmental protection requirements can be met without using desulphurization and desulfurization measures. In addition, bio-energy is free of waste water, waste gas, waste residue, dust and other pollution in the process of production and utilization, so clean production and utilization can be realized. Its environmental protection benefit is obvious too.

In the face of global situation of cooling economy and warming air, a series of finance and taxation preferential policies such as subsidies, rewards, fund and Tax reliefs have been unveiled by the government. These policies aim at energy conservation and emissions reduction, development of circular economy, utilization of clean energy, implementation of clean production and construction of ecological industrial park. So it's obvious that the policy benefit of using bio-energy is also prominent.

To sum up, bio-energy can be used not only to make comprehensive utilization of waste resources such as agricultural forest, but also to replace coal, fuel oil and natural gas. It can reduce the emission of $\mathrm{SO}_{2}, \mathrm{NO}_{\mathrm{X}}, \mathrm{CO}_{2}$, dust etc. As a kind of renewable green energy, it can also improve energy structure. Therefore, the development of bio-energy industry can achieve many things at one stroke and it's favorable to country, people and the future generations.

\footnotetext{
* Corresponding author: 434701098@qq.com
} 


\section{A case of using bio-energy}

There is a wide range and large amount of bio-energy source in China, the application prospect is spacious. Taking central heating project of Linan Banqiao town of Zhejiang province as a case, a model of district central heating using bio-energy is introduced here.

\subsection{The background of project construction}

The problem of air pollution in Zhejiang province is very serious in recent years. For example, Jiangsu, northern Zhejiang, northeastern Anhui, and Shanghai were polluted most severely among 74 cities in the event of "yellow haze in June", reaching severe haze.

Most hot users and industrial enterprises of Banqiao town are scattered disorderly before because of blind construction and lacking of unified planning, so the energy utilization rate is low and environmental pollution is serious.

In order to improve the air quality, many plans such as "action plan for preventing and controlling of air pollution in Zhejiang province (2013-2017)", “Implementation plan of constructing 'non-flammable coal areas' in Hangzhou city" are put forward by the government. A series of measures such as energy and industrial structure adjustment, motor vehicle exhaust pollution controlling, industrial waste gas pollution treatment, urban and rural waste management and so on are proposed in these plans. Source treatment, comprehensive control, green low carbon production and living styles are insisted. A new kind of atmospheric pollution preventing and controlling mechanism which is led by the government uniformly, realized treatment by enterprises, driven by market and participated by public is set up.

Many policies and measurements aiming at bioenergy are put forward specially in above-mentioned plans such as banning straw burning, making comprehensive implementation plan on utilization of straw and crop wastes, accelerating comprehensive utilization of straw and crop waste as well as encouraging straw reclamation and commercialization etc. Many concrete policies and regulations have been introduced in some places to improve previous scattered, disordered and poor condition of heat supply, gas supply and water supply.

The project of Banqiao town came into being under above-mentioned background.

\subsection{Brief introduction of present heating situation in Banqiao town}

Banqiao town is located in the southeast of Linan city and it's at the south side of Qingshan lake national forest park.

Paper-making is the pillar industry of the town and most of the hot users in this town are paper-making enterprises. The distribution of these enterprises is relatively scattered and their heating mode is coal boiler. There are 31 registered heating users, with 34 boilers and a total evaporation capacity of $91.7 \mathrm{t} / \mathrm{h}$. The current boilers of hot users in Banqiao town is mainly small boilers. The overall distribution situation of evaporation capacity and quantity of boilers is shown in the following table.

Table1 Boilers' evaporation capacity and quantity

\begin{tabular}{|c|c|c|c|c|c|c|}
\hline Evaporation(t/h) & $\leq 1$ & $\leq 2$ & $\leq 4$ & $\leq 5$ & $\leq 6$ & $\leq 8$ \\
\hline quantity & 6 & 18 & 5 & 1 & 3 & 1 \\
\hline
\end{tabular}

As figures in above table show, the only single maximum capacity of the boilers is $8 \mathrm{t} / \mathrm{h}$, and there are some more which are not contained in the above-mentioned table; the minimum is $0.4 \mathrm{t} / \mathrm{h}$. The average total thermal load is $57.0 \mathrm{t} / \mathrm{h}$, and the minimum thermal load is $47.8 \mathrm{t} / \mathrm{h}$, and the maximum is $73.1 \mathrm{t} / \mathrm{h}$.

The main problems of current heating mode are as follows. First, there is no unified plan on heating supply system. The heating system of every single enterprise is scattered and independent and their boiler room is arranged in chaos. The safety gap of these boilers is insufficient so there are hidden dangers. Second, the single boiler capacity is so small that the thermal efficiency is very low and the waste of coal, electricity and so on is enormous. Third, the dust removal equipment in coal-burning boiler room is backward and inefficient. Many low height chimneys make the urban air polluted seriously and this has affected the health of local people. Four, a great number of small boiler rooms scatter in the town and vehicles for coal and ash run across the township roads. Both urban traffic and town appearance are influenced.

Above-mentioned situation is incompatible with the development direction of making ecological industry as a priority, advocating integrated ecological industry, ecological leisure industry and ecological agriculture. So the township government decide to carry out centralized heating for 12 paper-making enterprises in the town.

\subsection{The content and scale of project construction}

\subsubsection{Fuel analysis}

Zhejiang province is lake of coal, The fuel coal in Hangzhou mainly comes from north area of the Yangtze river;but Banqiao is abundant in bamboo and bamboo powder can be gained from bamboo products processing factories nearby.

The heat value of bamboo powder is about half of that of coal, and a large amount of high-temperature flue gas is produced during the combustion of mixed bamboo powder, which can spare the use of partial coal and at the same time the purpose of utilization of bamboo powder disposal Is achieved.

An analysis of the relationship between fuel and demand is put forward as following table. 
Table 2 The relationship between fuel and demand

\begin{tabular}{|c|c|c|c|c|c|c|c|}
\hline \multirow{2}{*}{$\begin{array}{l}\text { Type } \\
\text { of } \\
\text { fuel }\end{array}$} & \multicolumn{3}{|c|}{$\begin{array}{l}\text { Industrial } \\
\text { customers }\end{array}$} & \multicolumn{2}{|c|}{$\begin{array}{l}\text { Commercial } \\
\text { customers }\end{array}$} & \multicolumn{2}{|c|}{$\begin{array}{l}\text { Civil } \\
\text { customers }\end{array}$} \\
\hline & $\begin{array}{l}\text { sin-gle } \\
\text { com- } \\
\text { pany }\end{array}$ & $\begin{array}{l}\text { group } \\
\text { custo- } \\
\text { mer }\end{array}$ & $\begin{array}{l}\text { indus- } \\
\text { trial } \\
\text { park }\end{array}$ & $\begin{array}{l}\text { single } \\
\text { heat- } \\
\text { ing }\end{array}$ & $\begin{array}{l}\text { coge- } \\
\text { ner } \\
\text {-ati } \\
\text {-on }\end{array}$ & $\begin{array}{l}\text { com- } \\
\text { merc- } \\
\text { ial } \\
\text { refri- } \\
\text { gera- } \\
\text { tion }\end{array}$ & $\begin{array}{l}\text { centr- } \\
\text { al } \\
\text { heat- } \\
\text { ing }\end{array}$ \\
\hline $\begin{array}{l}\text { Natu- } \\
\text { ral gas }\end{array}$ & $\sqrt{ }$ & & $\sqrt{ }$ & $\sqrt{ }$ & $\sqrt{ }$ & & $\sqrt{ }$ \\
\hline $\begin{array}{l}\text { Biom- } \\
\text { ass }\end{array}$ & & $\sqrt{ }$ & $\sqrt{ }$ & & & & \\
\hline $\begin{array}{l}\text { Clean } \\
\text { coal }\end{array}$ & & & $\sqrt{ }$ & & & & \\
\hline $\begin{array}{l}\text { Electri } \\
\text {-city }\end{array}$ & & & & & & $\sqrt{ }$ & \\
\hline
\end{tabular}

According to the relevant national energy conservation policy, it is encouraged to rationally use biomass solid waste such as bamboo powder as energy, and combing the analysis of table 2 , a mixture material of coal and bamboo powder is used as fuel, and their ratio is $7: 3$.

Fluidized bed combustion method is adopted in the boilers to ensure an intensive mix of the air and bamboo powder. A complete burning process can be guaranteed and oxygen content of exit flue gas of furnace is kept at 6 $\sim 8 \%$. Bamboo powder is a kind of solid object which is formed of various fine particles, so the combustion style is agglomeration combustion. Elutriation loss can be reduced through using fluidized bed.

\subsubsection{Heat supply station}

A heat supply station will be built and $250 \mathrm{~T} / \mathrm{H}$ circulating fluidized bed boilers are used in the station. $13.8 \mathrm{KM}$ steam pipes and several kilometers of condensate recovery pipes will be laid.

Limestone - gypsum wet desulfurization device is used as purification facility in the process to protect the environment. The sulphur removal efficiency is $98 \%$ 。

Further energy conservation measurements are taken as follows.

$\cdot 10 \mathrm{KV}$ high power motor is used to reduce the line loss.

-All the mechanical and electrical products selected are of high efficiency and energy-saving products are recommended by the state.

-Variable frequency regulation is adopted to secondary fan and IDF motor.

-Salt water is used to cool boiler bottom slag and the heat generated is recycled.

-Deaerator steam exhaust and boiler waste water are recycled to reduce energy consumption.

- Condensate return facility is used to recover heat and soften water so that both fuel and water resources are saved.

\subsection{Social impact analysis of the project}

The main beneficiaries of this project are those enterprises who use the steam. Moreover, the boiler owner and the local residents who near the steam users are beneficiaries too.

\subsubsection{Economic benefit analysis of the project}

Analyses of financial profitability, solvency, break-even, sensitivity show that the project has good profitability, quick investment recovery, strong ability to resist risks. So the boiler owner can also get better economic benefit.the project also has a positive effect on inviting investment. Some jobs have been provided for the town residents and the government tax revenue is increased too.

\subsubsection{Social benefit analysis of the project}

The project's annual steam capacity is 350000 tons, covering 16 hot users in Banqiao town.More than 20 small boilers have been eliminated and more than 40 local people have been employed.In the second phase of the project, all thermal enterprises within the radius of $10 \mathrm{KM}$ are considered to be included in central heating.

\subsubsection{Environmental benefit analysis of the project}

Not only The project guarantees thermal demand of the 12 paper-making enterprises, but also saves energy effectively. Environmental pollution can be reduced greatly. Still, the town is beautified by using space rationally.

Furthermore, The standards of air pollutant emission of the new boiler will conform to "GB13271-2014:Standards for discharge of atmospheric pollutants from boilers ". The specific emission limits are shown in the following table.

Table3 Boiler flue gas emission index

\begin{tabular}{|l|c|c|c|}
\hline \multicolumn{1}{|c|}{ Project } & Smoke and dust & $\mathrm{NO}$, & $\mathrm{SO}_{2}$ \\
\hline $\begin{array}{l}\text { Boiler } \\
\text { standard } \\
\text { values }\left(\mathrm{mg} / \mathrm{Nm}^{3}\right)\end{array}$ & 20 & 150 & 50 \\
\hline $\begin{array}{l}\text { Thermoelectric } \\
\text { unit standard } \\
\text { values }\left(\mathrm{mg} / \mathrm{Nm}^{3}\right)\end{array}$ & & & \\
\hline
\end{tabular}

After implementation of the project, the comprehensive thermal efficiency attain to $82.47 \%$. This is higher than the national requirement and $8603.88 \mathrm{t}$ coal is saved. Both environmental pollution and traffic congestion around the 12 paper-making enterprises are reduced so local environment is improved immensely.

In a word, the economic benefits, the environmental benefits and the social benefits of this project are obvious. As a useful case of bio-energy utilization, the project is worth popularizing and learning.

\section{References}

1. Jiang Yue and Zhang Baoxin, J, 2017 China's 
Biomass Energy Resources and Utilization Global Human Geography,008 (2017)

2. Yuan Zhenhong and Lei Tingzhou, J, 2017 The Analysis of Present Situation and Future Trend of Biomass Energy in China, Solar Energy,002 (2017)

3. Birkin F. Cashman A. Koh. S.C.L. and Liu, J, 2016 Z. New Sustainable Business Models in China, Business Strategy and the Environment, 005(2017)

4. Yang Yili, 2015 Study on Co-gasification Characteristics of Coal and Biomass Blends Master's thesis(North China Electric Power University)

5. Li Fei and Suocheng Dong, J, 2014 Energy consumption-economic growth relationship and carbon dioxide emissions in China Energy Policy, 002(2014)

6. The development strategy of bio-energy heating industry under the situation of constructing new urbanization and controlling atmospheric pollution ,2017 material of first biomass energy heating peak BBS meeting.

7. Zhang, N. and Jin H ,J,2011 The energy situation and its sustainable development strategy in China Energy 006(2011)

8. Midilli. A. Dincer, I. and Ay, M. ,J, 2006 Green energy strategies for sustainable development Energy Policy008 (2006)

9. Omer. A.M. J, 2012 Energy environment and sustainable development Renewable and sustainable energy reviews 009(2012)

10. Birkin F. Polesie T. and Lewis L. J, 2009 A new business model for sustainable development: an exploratory study using the theory of constraints in Nordic organizations Business Strategy and the Environment 005 (2009) 